\title{
SOIL ATTRIBUTES AND INITIAL CORN DEVELOPMENT AS A FUNCTION OF FERTILIZATION AND INTERCROPPING SYSTEMS
}

\author{
Jorge W. Cortez ${ }^{*}$, Rouverson P. da Silva ${ }^{2}$, Carlos E. A. Furlani ${ }^{2}$, Nelci Olszevski ${ }^{3}$, \\ Hideo de J. Nagahama ${ }^{3}$
}

\begin{abstract}
${ }^{1 *}$ Corresponding author. Universidade Federal da Grande Dourados/ Dourados - MS, Brasil.
E-mail: jorgecortez@ufgd.edu.br | ORCID: http://orcid.org/0000-0003-1120-719X
\end{abstract}

\section{KEYWORDS}

compaction, vegetation cover, soil physical quality.

\begin{abstract}
Fertilization systems that allow higher sowing speeds have been used in areas of grain production, as well as the use of intercropping to improve soil physical quality and provide better soil cover. This study aimed to evaluate soil attributes and the initial corn development and intercropping (corn + velvet bean, corn + pigeonpea, and corn + bonavist bean) as a function of fertilization systems (pre-sowing and sowing). The experiment was conducted in an Oxisol in a randomized block design in the $2 \times 3$ factorial scheme, with four replications. The number of days for emergence, plant stand, intercropping dry matter, soil straw cover, soil straw permanence index, penetration resistance, soil moisture, soil density, degree of compaction, and total soil porosity were measured. The percentage of soil straw cover was affected by fertilization system, mainly by pre-sowing fertilization. Soil physical attributes were not affected by fertilization and intercropping systems, except total porosity, in the $0-0.10 \mathrm{~m}$ layer, which has a combined effect of factors. The initial corn development was not affected by fertilization and intercropping systems. Velvet bean presented the highest number of days for the emergence and lower dry matter.
\end{abstract}

\section{INTRODUCTION}

The cultivated area increases as the demand for new production technologies also increases. Therefore, it is essential that alternatives be designed to reduce impacts and promote productivity gains, without compromising crop energy balance, as well as contributing to the improvement of soil physical, chemical, and biological conditions (Pereira et al., 2013; Cardoso et al., 2014).

The use of cover crops may lead to improvements in soil quality, microbial biomass, water storage, carbon sequestration, and improved nutrient supply to plants (Frasier et al., 2016). Plant stand is one of the main production components that changes crop productivity, maximizing the production environment for the crop (Ortiz et al., 2015).

Corn plants need adequate conditions of solar radiation interception, which is a direct function of population density and plant distribution in the area (Storck et al., 2015). Corn intercropped with legumes generates an advantage because its physiology is more efficient in carbon sequestration and dry matter accumulation at high temperatures, with a beneficial effect in subsequent years in the same intercropping area (Paz et al., 2012).

A conservationist system aims to promote adequate conditions for crop residue accumulation, which benefit water absorption and infiltration, increasing soil sorption, total porosity, and macro-aggregation (Sá et al., 2014). Despite the benefits, the occurrence of soil surface compaction has been observed in no-tillage systems, as well as a consequent increase in soil penetration resistance and reduction of porosity (Gozubuyuk et al., 2014).

The use of soil management systems provides changes, especially in its structure. In the long term, this aspect may be associated with the formation of compacted layers (Lima et al., 2013). Because soil management systems differ in their effect on aggregation indices and soil resistance, Betioli Junior et al. (2012) stated that one of the ways to increase soil structural quality is through the conservation and addition of organic matter in the soil.

${ }^{2}$ Universidade Estadual Paulista "Julio de Mesquita Filho"/ Jaboticabal - SP, Brasil.

${ }^{3}$ Universidade Federal do Vale do São Francisco/ Juazeiro - BA, Brasil.

Received in: 9-10-2018

Accepted in: 2-7-2019 
Vegetation cover hinders surface runoff, increasing the time and capacity of water infiltration, reduces the evaporation due to soil protection against solar radiation, and modifies the surface thermal amplitude at evaporation time (Cortez et al., 2015). A no-tillage system with adequate vegetation cover provides higher water savings and improved physical, chemical, and biological properties over the years when compared to other soil management systems (Silva et al., 2015).

Thus, the aim of this study was to evaluate soil attributes and the initial corn development and intercropping (corn + velvet bean, corn + pigeonpea, and corn + bonavist bean) in fertilization systems (pre-sowing and sowing).

\section{MATERIAL AND METHODS}

The experiment was conducted at the Experimental Farm of the University of São Paulo State (UNESP) in Jaboticabal. The study area has about 1.0 ha and is located on a typical Eutroferric Red Latosol, A moderate, clay texture (55\%), and soft wavy relief (average slope of $4 \%$ ), at the geodesic coordinates $21^{\circ} 14^{\prime} \mathrm{S}$ and $48^{\circ} 16^{\prime} \mathrm{W}$, and an average altitude of $559 \mathrm{~m}$. The data used as the basis for fertilization recommendation are shown in Table 1 . According to Köeppen's classification, the climate is $\mathrm{CWa}$, i.e. a subtropical humid climate, with drought in the winter season (Figure 1).

TABLE 1. Soil chemical analysis of the experimental area.

\begin{tabular}{|c|c|c|c|c|c|c|c|c|c|c|}
\hline Soil layer & $\mathrm{pH}$ & $\mathrm{MO}$ & $\mathrm{P}$ & $\mathrm{K}$ & $\mathrm{Ca}$ & $\mathrm{Mg}$ & $\mathrm{H}+\mathrm{Al}$ & SB & $\mathrm{T}$ & $\mathrm{V}$ \\
\hline $\mathrm{m}$ & $\mathrm{CaCl}_{2}$ & $\mathrm{~g} \mathrm{dm}^{-3}$ & $\mathrm{mg} \mathrm{dm}^{-3}$ & & & & $--\mathrm{mmc}$ & & -- & $\%$ \\
\hline $0-0.1$ & 6.0 & 28 & 46 & 4.8 & 50 & 30 & 20 & 85 & 105 & 81 \\
\hline $0.1-0.2$ & 5.7 & 23 & 37 & 4.5 & 38 & 17 & 25 & 60 & 85 & 70 \\
\hline
\end{tabular}

OM: organic matter; P: resin phosphorus; SB: sum of bases; T: cation exchange capacity at pH 7.0; V: soil base saturation.

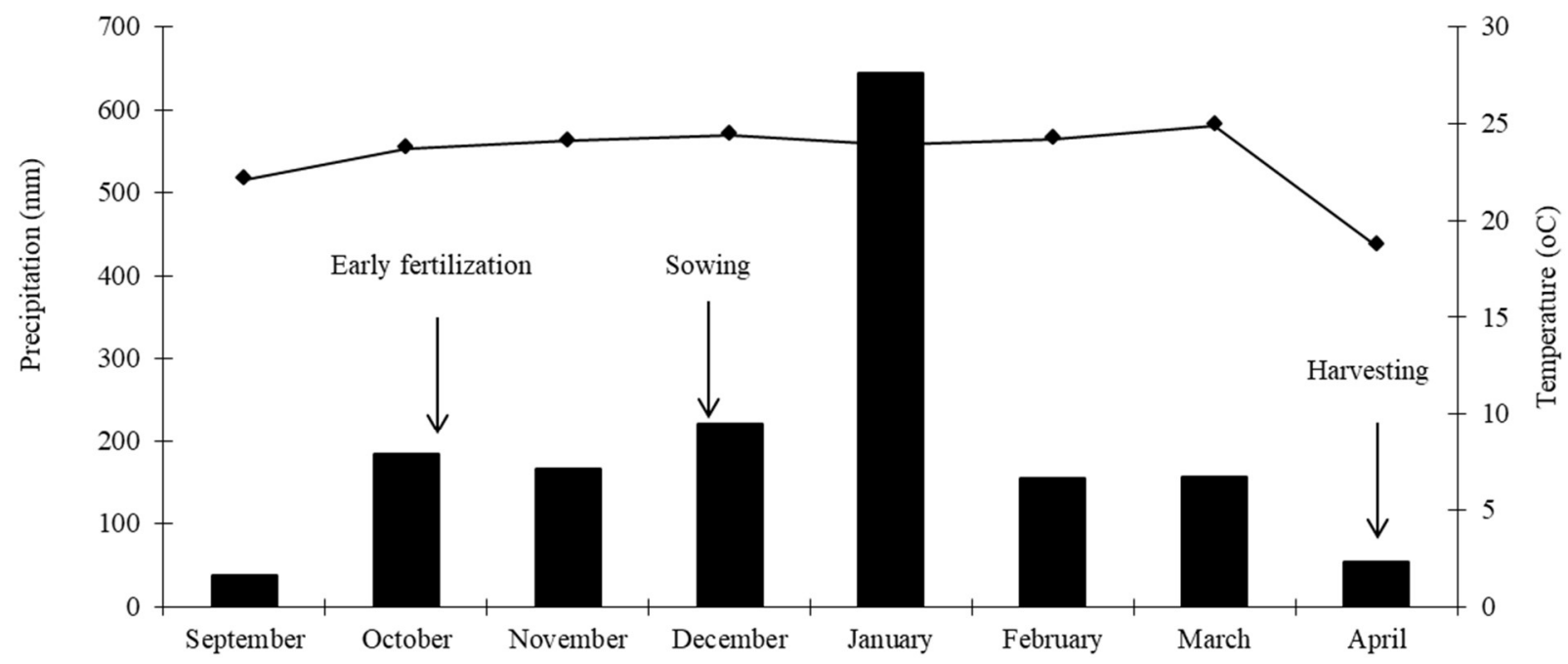

Months

Precipitation $(\mathrm{mm}) \longrightarrow$ Temperature $\left({ }^{\circ} \mathrm{C}\right)$

FIGURE 1. Monthly meteorological data (precipitation and temperature) obtained from the Department of Exact Sciences, UNESP, Jaboticabal, SP, Brazil.

The experimental area was maintained under fallow for a long time, favoring the infestation by guinea grass (Panicum maximum Jacq.) and bermudagrass (Cynodon dactylon (L.) Pers), which were mowed before the conventional soil tillage, with a heavy harrowing and two light harrowings. This area was used for planting different crops for eight years with fallow periods. Thus, before the experiment setup, millet (Pennisetum sp.) was sown in the area aiming at forming straw for soybean (Glycine $\max$ (L.) Merrill) direct sowing, which was carried out after seven months. After soybean harvesting, Crotalaria juncea L. and velvet bean (Stizolobium niveum L.) were sown in the area; corn (Zea mays L.) was sown after eight months. After four months, millet (Pennisetum glaucum (L.) R. Brown) and sorghum (Sorghum bicolor) were sown and soybean after eight months. Subsequently, crotalaria and velvet bean (Mucuna pruriens) were sown after soybean harvesting and corn were sown after eight months. After the corn harvesting, the area remained under fallow for eight months until soybean sowing. The area remained under fallow again for a year after soybean harvesting until the experiment was set up. At sowing time, soil presented $25 \%$ moisture in the $0-0.20$ m layer, $67.2 \%$ vegetation cover according to Laflen et al. (1981), and penetration resistance of 1.3 and $3.1 \mathrm{MPa}$ in the 0.00 0.10 and $0.10-0.20 \mathrm{~m}$ layers, respectively.

The experiment was set up in a randomized block design in a $2 \times 3$ factorial scheme with four replications, two fertilization systems (pre-sowing and sowing), and three intercropping systems (corn + velvet bean, corn + pigeonpea, and corn + bonavist bean). Each experimental plot occupied an area of $300 \mathrm{~m}^{2}(25 \times 12 \mathrm{~m})$ and a space 
of $15 \mathrm{~m}$ was reserved in the longitudinal direction between plots for maneuvers, machinery traffic, and stabilization of the mechanized assemblies during sowing and other operations.

Fertilizer application in pre-sowing was performed with a tractor-seeder assembly at a speed of $4.2 \mathrm{~km} \mathrm{~h}^{-1}$ thirty days before sowing. At sowing, this treatment received only seeds and the fertilizer mechanism (furrowing ridger) was removed from the seeder. Tractorseeder assembly speed was $6.6 \mathrm{~km} \mathrm{~h}^{-1}$. Fertilizer application at sowing used a seeder with all the mechanisms of contact with the soil, including the furrowing ridger for fertilizer deposition.

Intercropping (corn + velvet bean, corn + pigeonpea, and corn + bonavist bean) was formed at sowing time, with legume seeds deposited seven centimeters deep in the soil and corn seeds three centimeters deep in order to obtain a delay in the intercropping emergence. At sowing, seed deposits of the seeder lines were alternately filled with corn and legume seeds.

The tractor-seeder-fertilizer assembly used in this study comprised a seeder-fertilizer (model Marchesan COP Suprema) with seven sowing rows spaced at $0.45 \mathrm{~m}$ and weight of $3,070 \mathrm{~kg}$ coupled to a tractor (model Valtra BM100) with auxiliary front-wheel drive (AFWD), power of $73.6 \mathrm{~kW}$, and weight of $5,400 \mathrm{~kg}$, and.

The simple corn hybrid DKB 390, with purity and germination of $96 \%$ and 60,000 plants per hectare, maturation close to 120 days (mean cycle), first ear height of 1.25 to $1.40 \mathrm{~m}$, thermal summation until flowering of 870 degree-days, was used at sowing. Legumes used in the intercropping consisted of pigeonpea (Cajanus cajan L.), velvet bean (Stizolobium deeringianum Bort.), and bonavist bean (Dolichos lablab), with a density of 12, 9, and, 9 seeds per meter, respectively.

For pre-sowing and sowing fertilization, $370 \mathrm{~kg}$ $\mathrm{ha}^{-1}$ of the NPK formula 8-28-16 were applied. In addition, topdressing fertilization was carried out with 140 $\mathrm{kg} \mathrm{ha}^{-1}$ of urea at 14 days after sowing (V4 - four leaves) and $200 \mathrm{~kg} \mathrm{ha}^{-1}$ of urea at 30 days after sowing (V7 seven leaves).

The soil cover was measured with a $7.5 \mathrm{~m}$ long wire with equidistant markings of $0.15 \mathrm{~m}$ and two poles at the tips to fix it to the ground, resulting in 50 reading points and two readings on the diagonals of the plot, totaling 100 points (adapted from Laflen et al., 1981). The percentage of vegetation cover on the soil surface was determined at different times during the experimental period. Soil cover was determined after pre-sowing fertilization (CTa), at 30 days after pre-sowing fertilization $(\mathrm{CTb})$, and after sowing $(\mathrm{CTc})$; the straw permanence index (PI) of corn (CTd), intercropping (CTe), and weeds (CTf) at 30 days after sowing; and bare soil at 30 days after sowing (CTg). PI is the relationship between post- and pre-sowing cover and was obtained from these evaluations.
Data were collected from the emergence of corn and intercropped plants to the stabilization of the number of seedlings emerged in two meters marked in the central part of the plot. The mean number of days for emergency (NDE) was determined according to Edmond \& Drapala (1958). A one-meter wooden batten with a wooden handle, forming an inverted " $T$ ", was used to determine the initial plant stand (PS). In the field, the initial part of this equipment was placed next to corn or intercropped plants and the number of plants emerged in this space was counted. Counts were carried out in the central row of each plot in two meters.

Five consecutive plants were collected from the central part of the plot in order to determine the intercropping dry matter (IDM) at 30, 60, and 90 days after sowing (DAS), being oven dried at $70{ }^{\circ} \mathrm{C}$ for 48 hours until constant weight.

Penetration resistance (PR) was determined with an IAA/Planalsucar impact penetrometer (Stolf et al., 1983) with a $4 \mathrm{~kg}$ plunger mass, $40 \mathrm{~cm}$ free fall course, $30^{\circ}$ cone angle, $1.3 \mathrm{~cm}$ in diameter and rod with a diameter of 0.95 $\mathrm{cm}$. Readings were performed in all the experimental plots (one per plot) at 30 days after the sowing operation in the interrow, with values taken every $0.10 \mathrm{~m}$ at a depth of 0.50 $\mathrm{m}$. The results were taken in blows $\mathrm{dm}^{-1}$ and transformed into MPa, as described by Stolf (1991).

Soil gravimetric moisture (SM), soil density (SD), and total soil porosity (TP) were determined according to the methodology of Donagema et al. (2011) from samples collected in the $0.00-0.10,0.10-0.20$, and $0.20-0.30 \mathrm{~m}$ layers within each plot at 30 days after sowing operation.

In addition, the degree of compaction, defined as the percentage of compaction that the soil has in relation to its maximum (Suzuki et al., 2007), was calculated. The maximum density value for the Eutroferric Red Latosol of the area is $1.85 \mathrm{~g} \mathrm{~cm}^{-3}$ (Beutler et al., 2005).

The data were submitted to analysis of variance and when the value of the F-test was significant at 5\% probability, the Tukey's test was performed at 5\% probability for the comparison of means.

\section{RESULTS AND DISCUSSION}

Soil cover after pre-sowing fertilization (Table 2) presented differences between fertilization systems. Thus, pre-sowing fertilization reduced soil cover by $43.1 \%$. This is due to the amount of clay in the soil, which adheres to the seeder-fertilizer mechanisms, opening a wide groove and burying the straw. According to Francetto et al. (2015), this occurs due to the dimensional characteristics of the elements that interfere with the cutting, shear, and compaction stresses caused to the soil. After pre-sowing fertilization (30 days), soil cover increased by $8.8 \%$, while at the site of fertilization only sowing increased by $6.1 \%$. 
TABLE 2. Summary of analysis of variance for soil cover after pre-sowing fertilization (CTa), at 30 days after pre-sowing fertilization $(\mathrm{CTb})$, and after sowing $(\mathrm{CTc})$; the straw permanence index of corn (CTd), intercropping (CTe), and weeds (CTf) at 30 days after sowing; and bare soil at 30 days after sowing $(\mathrm{CTg})$.

\begin{tabular}{lcccccccc}
\hline \multirow{2}{*}{ Factor } & \multicolumn{7}{c}{ Soil cover (\%) } \\
\cline { 2 - 8 } & $\mathrm{CTa}$ & $\mathrm{CTb}$ & $\mathrm{CTc}$ & $\mathrm{IP}$ & $\mathrm{CTd}$ & $\mathrm{CTe}$ & $\mathrm{CTf}$ & $\mathrm{CTg}$ \\
\hline Fertilization & & & & & & & & \\
Pre-sowing & $36.6 \mathrm{~B}$ & $45.4 \mathrm{~B}$ & $22.6 \mathrm{~A}$ & $50.3 \mathrm{~A}$ & $38.7 \mathrm{~B}$ & $16.6 \mathrm{~A}$ & $31.5 \mathrm{~A}$ & $13.2 \mathrm{~A}$ \\
Sowing & $64.3 \mathrm{~A}$ & $70.4 \mathrm{~A}$ & $23.6 \mathrm{~A}$ & $34.0 \mathrm{~B}$ & $50.1 \mathrm{~A}$ & $17.7 \mathrm{~A}$ & $19.6 \mathrm{~B}$ & $12.6 \mathrm{~A}$ \\
\hline Intercropping & & & & & & & & \\
C + velvet bean & $46.9 \mathrm{~A}$ & $58.0 \mathrm{~A}$ & $22.0 \mathrm{~A}$ & $40.1 \mathrm{~A}$ & $43.6 \mathrm{~A}$ & $6.4 \mathrm{C}$ & $27 \mathrm{AB}$ & $22.7 \mathrm{~A}$ \\
C + pigeonpea & $59.0 \mathrm{~A}$ & $59.2 \mathrm{~A}$ & $24.0 \mathrm{~A}$ & $42.1 \mathrm{~A}$ & $45.2 \mathrm{~A}$ & $14.4 \mathrm{~B}$ & $30.6 \mathrm{~A}$ & $9.7 \mathrm{~B}$ \\
C + bonavist bean & $45.5 \mathrm{~A}$ & $56.5 \mathrm{~A}$ & $23.2 \mathrm{~A}$ & $44.2 \mathrm{~A}$ & $44.2 \mathrm{~A}$ & $30.9 \mathrm{~A}$ & $18.7 \mathrm{~B}$ & $6.1 \mathrm{~B}$ \\
\hline F-test & & & & & & & \\
Fertilization (F) & $39.2^{* *}$ & $29.2^{* *}$ & $0.1^{\mathrm{ns}}$ & $10.2^{* *}$ & $21.9^{* *}$ & $0.4 \mathrm{~ns}$ & $12.7^{* *}$ & $0.1 \mathrm{~ns}$ \\
Intercropping (I) & $3.7^{*}$ & $0.1^{\mathrm{ns}}$ & $0.1^{\mathrm{ns}}$ & $0.2^{\mathrm{ns}}$ & $0.1^{\mathrm{ns}}$ & $67.6^{* *}$ & $4.5^{*}$ & $19.0^{* *}$ \\
F $\times$ I & $1.1^{\mathrm{ns}}$ & $0.1^{\mathrm{ns}}$ & $1.5^{\mathrm{ns}}$ & $2.0^{\mathrm{ns}}$ & $0.5^{\mathrm{ns}}$ & $0.6^{\mathrm{ns}}$ & $1.5^{\mathrm{ns}}$ & $1.2^{\mathrm{ns}}$ \\
\hline CV (\%) & 21.5 & 19.6 & 35.7 & 29.1 & 13.5 & 24.9 & 32.1 & 44.0 \\
\hline
\end{tabular}

Means followed by the same letter in the column do not differ from each other by the Tukey's test. ${ }^{\text {ns. }}$ not significant $(\mathrm{P}>0.05)$;

*: significant $(\mathrm{P}<0.05)$; **: significant $(\mathrm{P}<0.01)$. C: corn. $\mathrm{CV}$ : coefficient of variation $(\%)$.

After sowing, a marked reduction was observed in soil cover with intercropping installation (Table 2), but with no difference between fertilization and intercropping systems. Straw permanence index (PI) presented differences between fertilization systems, evidencing a higher soil cover in the pre-sowing fertilization system. Even with an initial reduction in soil cover by pre-sowing at 30 days after sowing, this treatment showed an increase of $47.9 \%$ when compared to sowing fertilization. This soil cover maximization may be associated with the lack of the furrowing ridge during the sowing operation. Thus, according to Nagahama et al. (2016), the use of disks for straw cutting should be used together with ridges in order to reduce straw incorporation, i.e. the use of only furrowing ridge in the seeder favors a soil cover reduction.

After sowing, soil cover was defined with corn, intercropping, and weeds, and in the bare soil (Table 2). For corn, a difference was observed between fertilization systems, demonstrating an effect on the initial crop development. According to Lacerda et al. (2015), this development is due to the characteristic of responsiveness of the species to fertilization, with the lowest soil cover observed in the pre-sowing fertilization. Intercropping presented differences regarding soil cover only between crops, with bonavist bean and velvet bean presenting the highest $(30.9 \%)$ and lowest soil cover (6.4\%), respectively. This result was due to the rapid initial growth of bonavist bean and slow of velvet bean. Soil cover by weeds was affected by fertilization and intercropping systems. Pre-sowing fertilization favored weed development, while pigeonpea (30.6\%) differed from the bonavist bean (18.7\%) in the intercropping. As observed, the highest value of bare soil was found in the intercropping system with velvet bean due to its lower initial development.

Soil cover (Table 2) is a criterion used to classify a system as being conservationist or non-conservationist. Thus, according to ASAE (1989), a conservationist system is that with a soil cover higher than $30 \%$ of residues after sowing. Marques \& Benez (2000) evaluated soil cover after sowing under no-tillage system managed with herbicide and using a seeder with furrowing ridge and verified a coverage of $81 \%$. In this sense, Furlani et al. (2004) observed a permanence of more than $60 \%$ in soil cover after sowing in a no-tillage system. Ziech et al. (2015) observed that the intercropping of plant species when compared to isolated crops, provided the formation of a soil cover closer to the ideal in terms of quantity and quality of residues, which brings benefits to crops in succession and no-tillage system.

Soil penetration resistance at 30 days after sowing (Table 3) presented no difference between fertilization and intercropping systems in all the evaluated layers. No increase in penetration resistance was observed even in the pre-sowing fertilization with an additional operation. According to Lima et al. (2015), cover plants that provide an increase in biopores also improve soil physical conditions considering the decompaction potential of some species. 
TABLE 3. Summary of analysis of variance for soil penetration resistance (MPa) 30 days after sowing.

\begin{tabular}{|c|c|c|c|c|c|}
\hline \multirow[b]{2}{*}{ Factor } & \multicolumn{5}{|c|}{ Layer (m) } \\
\hline & $0.00-0.10$ & $0.10-0.20$ & $0.20-0.30$ & $0.30-0.40$ & $0.40-0.50$ \\
\hline \multicolumn{6}{|l|}{ Fertilization } \\
\hline Pre-sowing & $0.8 \mathrm{~A}$ & $2.1 \mathrm{~A}$ & $3.4 \mathrm{~A}$ & $4.1 \mathrm{~A}$ & $4.5 \mathrm{~A}$ \\
\hline Sowing & $1.1 \mathrm{~A}$ & $2.4 \mathrm{~A}$ & $2.9 \mathrm{~A}$ & $3.5 \mathrm{~A}$ & $3.8 \mathrm{~A}$ \\
\hline \multicolumn{6}{|l|}{ Intercropping } \\
\hline $\mathrm{C}+$ velvet bean & $0.8 \mathrm{~A}$ & $2.1 \mathrm{~A}$ & $2.8 \mathrm{~A}$ & $3.6 \mathrm{~A}$ & $3.8 \mathrm{~A}$ \\
\hline $\mathrm{C}+$ pigeonpea & $1.1 \mathrm{~A}$ & $2.4 \mathrm{~A}$ & $3.2 \mathrm{~A}$ & $3.6 \mathrm{~A}$ & $4.4 \mathrm{~A}$ \\
\hline$\underline{\mathrm{C}}+$ bonavist bean & $0.9 \mathrm{~A}$ & $2.1 \mathrm{~A}$ & $3.5 \mathrm{~A}$ & $4.2 \mathrm{~A}$ & $4.3 \mathrm{~A}$ \\
\hline \multicolumn{6}{|l|}{ F-test } \\
\hline Fertilization (F) & $2.9^{\mathrm{ns}}$ & $1.8^{\mathrm{ns}}$ & $2.4^{\mathrm{ns}}$ & $2.1^{\mathrm{ns}}$ & $1.2^{\mathrm{ns}}$ \\
\hline Intercropping (I) & $1.0^{\mathrm{ns}}$ & $0.5^{\mathrm{ns}}$ & $2.3^{\mathrm{ns}}$ & $0.9^{\mathrm{ns}}$ & $0.3^{\mathrm{ns}}$ \\
\hline$\underline{\mathrm{F} \times \mathrm{I}}$ & $0.3^{\mathrm{ns}}$ & $0.5^{\mathrm{ns}}$ & $0.5^{\mathrm{ns}}$ & $0.6^{\mathrm{ns}}$ & $0.7^{\mathrm{ns}}$ \\
\hline $\mathrm{CV}(\%)$ & 48.4 & 27.7 & 22.2 & 26.6 & 36.1 \\
\hline
\end{tabular}

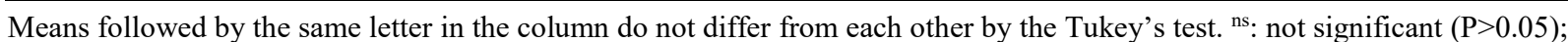

*: significant $(\mathrm{P}<0.05)$; **: significant $(\mathrm{P}<0.01)$. C: corn. $\mathrm{CV}$ : coefficient of variation $(\%)$.

Penetration resistance (PR) increased as depth increased up to the $0.30-0.40$ and $0.40-0.50 \mathrm{~m}$ layers. In a study with mechanized assemblies of soil tillage, Nagahama et al. (2016) also observed an increased PR as depth increased mainly due to the natural overlap of soil layers. Soil moisture at the measurement time of penetration resistance was between 0.25 and $0.27 \mathrm{~cm}^{3}$ $\mathrm{cm}^{-3}$ in the soil layer of $0.00-0.50 \mathrm{~m}$.

In areas of no-tillage system, it is expected a higher soil penetration resistance, especially below $0.10 \mathrm{~m}$ because this layer is usually affected by machinery traffic. According to Beutler \& Centurion (2004), medium levels of penetration resistance of $2.55 \mathrm{MPa}$ have been observed for clay soils when managed under a conventional tillage system. Other authors define as $2.0 \mathrm{MPa}$ the limit above which restrictions occur to the root system, being this value usually found below the $0.10-0.20 \mathrm{~m}$ layer (Suzuki, 2005). In addition, according to Souza et al. (2014), PR increases exponentially as moisture decreases due to an increase of cohesive forces between soil particles.

Density and the degree of soil compaction were not affected by fertilization and intercropping systems (Table 4). Mean values of density of $1.5 \mathrm{~g} \mathrm{~cm}^{-3}$ and degree of compaction of $76 \%$ were observed in the 0.00 $0.10 \mathrm{~m}$ layer and $80 \%$ in the $0.10-0.20$ and $0.20-0.30 \mathrm{~m}$ layers. According to Torres et al. (2015), positive and negative correlations between soil density and other soil physical attributes show its importance as a good indicator of soil quality.

TABLE 4. Summary of analysis of variance for soil density (SD) and degree of soil compaction (DC) in the $0.00-0.10,0.10$ 0.20 , and $0.20-0.30 \mathrm{~m}$ layers.

\begin{tabular}{|c|c|c|c|c|c|c|}
\hline \multirow{2}{*}{ Factor } & \multicolumn{3}{|c|}{$\mathrm{SD}\left(\mathrm{g} \mathrm{cm}^{-3}\right)$} & \multicolumn{3}{|c|}{$\mathrm{DC}(\%)$} \\
\hline & $0-0.1 \mathrm{~m}$ & $0.1-0.2 \mathrm{~m}$ & $0.2-0.3 \mathrm{~m}$ & $0-0.1 \mathrm{~m}$ & $0.1-0.2 \mathrm{~m}$ & $0.2-0.3 \mathrm{~m}$ \\
\hline \multicolumn{7}{|l|}{ Fertilization } \\
\hline Pre-sowing & $1.4 \mathrm{~A}$ & $1.4 \mathrm{~A}$ & $1.5 \mathrm{~A}$ & $77.3 \mathrm{~A}$ & $80.7 \mathrm{~A}$ & $80.8 \mathrm{~A}$ \\
\hline Sowing & $1.4 \mathrm{~A}$ & $1.5 \mathrm{~A}$ & $1.5 \mathrm{~A}$ & $76.1 \mathrm{~A}$ & $81.5 \mathrm{~A}$ & $81.1 \mathrm{~A}$ \\
\hline \multicolumn{7}{|l|}{ Intercropping } \\
\hline $\mathrm{C}+$ velvet bean & $1.4 \mathrm{~A}$ & $1.4 \mathrm{~A}$ & $1.5 \mathrm{~A}$ & $76.0 \mathrm{~A}$ & $82.1 \mathrm{~A}$ & $81.3 \mathrm{~A}$ \\
\hline $\mathrm{C}+$ pigeonpea & $1.5 \mathrm{~A}$ & $1.5 \mathrm{~A}$ & $1.5 \mathrm{~A}$ & $77.9 \mathrm{~A}$ & $81.4 \mathrm{~A}$ & $80.8 \mathrm{~A}$ \\
\hline $\mathrm{C}+$ bonavist bean & $1.4 \mathrm{~A}$ & $1.5 \mathrm{~A}$ & $1.5 \mathrm{~A}$ & $76.1 \mathrm{~A}$ & $79.9 \mathrm{~A}$ & $80.7 \mathrm{~A}$ \\
\hline \multicolumn{7}{|l|}{ F-test } \\
\hline Fertilization (F) & $0.5^{\mathrm{ns}}$ & $1.7^{\mathrm{ns}}$ & $0.9^{\mathrm{ns}}$ & $1.5^{\mathrm{ns}}$ & $0.4^{\mathrm{ns}}$ & $0.1^{\mathrm{ns}}$ \\
\hline Intercropping (I) & $2.8^{\mathrm{ns}}$ & $0.4^{\mathrm{ns}}$ & $0.6^{\mathrm{ns}}$ & $1.6^{\mathrm{ns}}$ & $1.0^{\mathrm{ns}}$ & $0.2^{\mathrm{ns}}$ \\
\hline $\mathrm{F} \times \mathrm{I}$ & $1.7 \mathrm{~ns}$ & $0.6^{\mathrm{ns}}$ & $0.2^{\mathrm{ns}}$ & $0.3^{\mathrm{ns}}$ & $1.7^{\mathrm{ns}}$ & $1.2^{\mathrm{ns}}$ \\
\hline CV (\%) & 3.9 & 14.9 & 3.1 & 3.2 & 3.9 & 2.6 \\
\hline
\end{tabular}

Means followed by the same letter in the column do not differ from each other by the Tukey's test. ${ }^{\text {ns: }}$ not significant $(\mathrm{P}>0.05)$;

*: significant $(\mathrm{P}<0.05)$; **: significant $(\mathrm{P}<0.01)$. C: corn. $\mathrm{CV}$ : coefficient of variation $(\%)$.

Soil moisture and total soil porosity were not affected by fertilization and intercropping systems (Table 5 ), except for total porosity in the $0.00-0.10 \mathrm{~m}$ layer, which had a combined action from fertilization and intercropping systems (Table 6). The mean values of moisture varied from 0.250 to $0.280 \mathrm{~cm}^{3} \mathrm{~cm}^{-3}$, whereas the mean values of total porosity varied around $40 \%$.
Soils with vegetation cover are less affected by the impact of rainwater with consequent increase of infiltration. When the soil is under the drying process, vegetation cover retains soil moisture better. Therefore, according to Oliveira et al. (2000), the moisture of the soil profile is evenly distributed, especially when it is under the notillage system. 
TABLE 5. Summary of analysis of variance for soil moisture (SM) and total soil porosity (TP) at 30 days after sowing in the $0-0.30$ m layers.

\begin{tabular}{|c|c|c|c|c|c|c|}
\hline \multirow{2}{*}{ Factor } & \multicolumn{3}{|c|}{$\mathrm{SM}\left(\mathrm{cm}^{3} \mathrm{~cm}^{-3}\right)$} & \multicolumn{3}{|c|}{$\mathrm{TP}(\%)$} \\
\hline & $0-0.1 \mathrm{~m}$ & $0.1-0.2 \mathrm{~m}$ & $0.2-0.3 \mathrm{~m}$ & $0-0.1 \mathrm{~m}$ & $0.1-0.2 \mathrm{~m}$ & $0.2-0.3 \mathrm{~m}$ \\
\hline \multicolumn{7}{|l|}{ Fertilization } \\
\hline Pre-sowing & $0.283 \mathrm{~A}$ & $0.255 \mathrm{~A}$ & $0.266 \mathrm{~A}$ & $40.7 \mathrm{~A}$ & $39.3 \mathrm{~A}$ & $40.2 \mathrm{~A}$ \\
\hline Sowing & $0.277 \mathrm{~A}$ & $0.259 \mathrm{~A}$ & $0.266 \mathrm{~A}$ & $40.8 \mathrm{~A}$ & $39.5 \mathrm{~A}$ & $40.1 \mathrm{~A}$ \\
\hline \multicolumn{7}{|l|}{ Intercropping } \\
\hline $\mathrm{C}+$ velvet bean & $0.285 \mathrm{~A}$ & $0.262 \mathrm{~A}$ & $0.266 \mathrm{~A}$ & $40.7 \mathrm{~A}$ & $39.9 \mathrm{~A}$ & $40.0 \mathrm{~A}$ \\
\hline $\mathrm{C}+$ pigeonpea & $0.271 \mathrm{~A}$ & $0.247 \mathrm{~A}$ & $0.264 \mathrm{~A}$ & $39.9 \mathrm{~A}$ & $38.4 \mathrm{~A}$ & $40.2 \mathrm{~A}$ \\
\hline $\mathrm{C}+$ bonavist bean & $0.284 \mathrm{~A}$ & $0.267 \mathrm{~A}$ & $0.267 \mathrm{~A}$ & $41.5 \mathrm{~A}$ & $40.0 \mathrm{~A}$ & $40.3 \mathrm{~A}$ \\
\hline \multicolumn{7}{|l|}{ F-test } \\
\hline Fertilization (F) & $1.6^{\mathrm{ns}}$ & $0.3^{\mathrm{ns}}$ & $0.1^{\mathrm{ns}}$ & $0.1^{\mathrm{ns}}$ & $0.1^{\mathrm{ns}}$ & $0.1^{\mathrm{ns}}$ \\
\hline Intercropping (I) & $3.5^{\mathrm{ns}}$ & $1.6^{\mathrm{ns}}$ & $0.1^{\mathrm{ns}}$ & $3.3^{\mathrm{ns}}$ & $1.0^{\mathrm{ns}}$ & $0.1^{\mathrm{ns}}$ \\
\hline $\mathrm{F} \times \mathrm{I}$ & $2.4^{\mathrm{ns}}$ & $2.5^{\mathrm{ns}}$ & $1.8^{\mathrm{ns}}$ & $5.1 *$ & $1.8^{\mathrm{ns}}$ & $0.2^{\mathrm{ns}}$ \\
\hline CV (\%) & 4.1 & 7.1 & 3.9 & 3.0 & 6.3 & 3.1 \\
\hline
\end{tabular}

Means followed by the same letter in the column do not differ from each other by the Tukey's test. ${ }^{\text {ns: }}$ not significant $(\mathrm{P}>0.05)$;

*: significant $(\mathrm{P} \leq 0.05)$; **: significant $(\mathrm{P} \leq 0.01)$. C: corn. $\mathrm{CV}$ : coefficient of variation $(\%)$.

The total porosity underwent a combined action of fertilization and intercropping systems in the $0.00-0.10 \mathrm{~m}$ layer (Table 6). In this sense, pre-sowing fertilization had the lowest porosity in the intercropping with pigeonpea. This may be associated with the root system development because Matoso et al. (2015) observed a considerable improvement in total porosity due to the higher amount of roots in the soil.

TABLE 6. Summary of the slicing of the interaction fertilization (F) and intercropping (I) for the total porosity in the 0.00 0.10 m layer.

\begin{tabular}{lcc}
\hline & \multicolumn{2}{c}{ Fertilization } \\
\cline { 2 - 3 } Intercropping & Pre-sowing & Sowing \\
\hline C + velvet bean & $41.5 \mathrm{Aa}$ & $39.9 \mathrm{Aa}$ \\
$\mathrm{C}+$ pigeonpea & $38.8 \mathrm{Bb}$ & $41.1 \mathrm{Aa}$ \\
$\mathrm{C}+$ bonavist bean & $41.8 \mathrm{Aa}$ & $41.3 \mathrm{Aa}$ \\
\hline
\end{tabular}

Means followed by the same uppercase letter in the column and lowercase letter in the row do not differ from each other by the Tukey's test at $5 \%$ probability. C: corn.

In the sowing fertilization system, no difference was observed between intercropping systems (Table 6). Only the intercropping with pigeonpea differed in the fertilization systems, with the lowest porosity in the presowing.

The number of days for emergence (NDE) was not significant for corn (Table 7), but a significant difference was observed for fertilization systems and crop types in the intercropping. Fertilization systems showed the need for a higher NDE in pre-sowing. Regarding the intercropping, differences were observed between crops, being higher for velvet bean, pigeonpea, and bonavist bean, even with seeds sown at a depth of $7 \mathrm{~cm}$. According to Alves et al. (2014), sowing depth is specific for each species and when it is appropriate, it provides uniform germination and emergence of seedlings, but excessive depths may prevent seedlings from emerging to the soil surface.

TABLE 7. Summary of analysis of variance for the number of days for the emergence of crops (NDEcrop), number of days for the emergence of corn (NDEcorn), initial corn stand (Scorn $\times 1000$ plants), and crop stand (Scrop $\times 1000$ plants).

\begin{tabular}{|c|c|c|c|c|}
\hline \multirow[b]{2}{*}{ Factor } & \multicolumn{4}{|c|}{ Variable } \\
\hline & NDEcrop & NDEcorn & Scorn & Scrop \\
\hline \multicolumn{5}{|l|}{ Fertilization } \\
\hline Pre-sowing & $5.5 \mathrm{~A}$ & $4.0 \mathrm{~A}$ & $67.6 \mathrm{~A}$ & $71.7 \mathrm{~A}$ \\
\hline Sowing & $5.2 \mathrm{~B}$ & $4.1 \mathrm{~A}$ & $64.4 \mathrm{~A}$ & $79.1 \mathrm{~A}$ \\
\hline \multicolumn{5}{|l|}{ Intercropping } \\
\hline $\mathrm{C}+$ velvet bean & $7.2 \mathrm{~A}$ & $4.0 \mathrm{~A}$ & $65.9 \mathrm{~A}$ & $31.9 \mathrm{~B}$ \\
\hline $\mathrm{C}+$ pigeonpea & $4.7 \mathrm{~B}$ & $4.1 \mathrm{~A}$ & $68.8 \mathrm{~A}$ & $103.5 \mathrm{~A}$ \\
\hline $\mathrm{C}+$ bonavist bean & $4.1 \mathrm{C}$ & $4.0 \mathrm{~A}$ & $63.2 \mathrm{~A}$ & $90.9 \mathrm{~A}$ \\
\hline \multicolumn{5}{|l|}{ F-test } \\
\hline Fertilization (F) & $4.8 *$ & $2.1^{\mathrm{ns}}$ & $0.9^{\mathrm{ns}}$ & $1.4^{\mathrm{ns}}$ \\
\hline Intercropping (I) & $213 * *$ & $2.1^{\mathrm{ns}}$ & $0.9^{\mathrm{ns}}$ & $51.0 * *$ \\
\hline$\underline{F} \times \mathrm{I}$ & $2.0^{\mathrm{ns}}$ & $0.1^{\mathrm{ns}}$ & $0.5^{\mathrm{ns}}$ & $0.2^{\mathrm{ns}}$ \\
\hline CV (\%) & 5.9 & 2.0 & 12.6 & 20.0 \\
\hline
\end{tabular}

Means followed by the same letter in the column do not differ from each other by the Tukey's test. ${ }^{\text {ns. }}$ not significant $(\mathrm{P}>0.05)$;

*: significant $(\mathrm{P} \leq 0.05)$; **: significant $(\mathrm{P} \leq 0.01)$. C: corn. $\mathrm{CV}$ : coefficient of variation $(\%)$. 
The initial corn stand (Scorn) did not differ between treatments (Table 6). The results of the initial stand were close to those recommended by the manufacturer. For intercropping systems, a difference was observed as a function of crops, being higher for pigeonpea and bonavist bean. Araldi et al. (2016) pointed out that seedling emergence is reduced by increasing sowing depth from 2 $\mathrm{cm}$, thus influencing stand establishment.

Intercropping dry matter (Table 8) showed a significant difference at 30,60, and 90 days. No difference was observed for fertilization systems at all periods. Bonavist bean presented the highest dry matter at all periods. At 30 days after sowing, velvet bean had the lowest dry matter and at 60 days after sowing, pigeonpea and velvet bean had the lowest dry matter. Herrada et al. (2017) pointed out that differences in the amount of dry matter and nitrogen of legumes, when intercropped under different proportions, should condition the decomposition and release dynamics of nitrogen after the species management.

TABLE 8. Summary of analysis of variance for intercropping dry matter (IDM).

\begin{tabular}{|c|c|c|c|}
\hline \multirow[b]{2}{*}{ Factors } & \multicolumn{3}{|c|}{ Intercropping dry matter $\left(\mathrm{kg} \mathrm{ha}^{-1}\right)$} \\
\hline & 30 days & 60 days & 90 days \\
\hline \multicolumn{4}{|l|}{ Fertilization } \\
\hline Pre-sowing & $415.0 \mathrm{~A}$ & $751.8 \mathrm{~A}$ & $860.7 \mathrm{~A}$ \\
\hline Sowing & $419.5 \mathrm{~A}$ & $646.6 \mathrm{~A}$ & $864.3 \mathrm{~A}$ \\
\hline \multicolumn{4}{|l|}{ Intercropping } \\
\hline $\mathrm{C}+$ velvet bean & $201.7 \mathrm{C}$ & $357.6 \mathrm{~B}$ & $472.2 \mathrm{~B}$ \\
\hline $\mathrm{C}+$ pigeonpea & $424.3 \mathrm{~B}$ & $659.6 \mathrm{~B}$ & $944.2 \mathrm{AB}$ \\
\hline $\mathrm{C}+$ bonavist bean & $625.8 \mathrm{~A}$ & $1080.3 \mathrm{~A}$ & $1171.3 \mathrm{~A}$ \\
\hline \multicolumn{4}{|l|}{ F-test } \\
\hline Fertilization (F) & $0.1^{\mathrm{ns}}$ & $0.9^{\mathrm{ns}}$ & $0.1^{\mathrm{ns}}$ \\
\hline Intercropping (I) & $75.9 * *$ & $14.3 * *$ & $5.1 *$ \\
\hline $\mathrm{F} \times \mathrm{I}$ & $0.2^{\mathrm{ns}}$ & $0.2^{\mathrm{ns}}$ & $0.1^{\mathrm{ns}}$ \\
\hline $\mathrm{CV}(\%)$ & 16.5 & 38.8 & 51.3 \\
\hline
\end{tabular}

Means followed by the same letter in the column do not differ from each other by the Tukey's test. ${ }^{\text {ns. }}$ not significant (P>0.05);

*: significant $(\mathrm{P} \leq 0.05)$;**: significant $(\mathrm{P} \leq 0.01)$. C: corn. $\mathrm{CV}$ : coefficient of variation $(\%)$.

\section{CONCLUSIONS}

The percentage of soil cover with straw was affected by the fertilization system, especially by the presowing fertilization.

The soil attributes density, degree of compaction, moisture, porosity, and penetration resistance were not affected by fertilization and intercropping systems. However, the total porosity in the surface layer underwent a combined effect of factors.

The initial corn development was not affected by fertilization and intercropping systems.

Velvet bean had the highest number of days for the emergence and the lowest dry matter at 90 days after sowing.

\section{ACKNOWLEDGMENTS}

To CAPES for granting the doctoral fellowship for the first author.

\section{REFERENCES}

Alves AU, Cardoso EA, Alixandre TF, Cavalcante IHL, Beckmann-Cavalcante MZ (2014) Emergência de plântulas de fava em função de posições e profundidades de semeadura. Bioscence Journal 30(1):33-42.

Araldi DA, Yamashita OM, Carvalho MAC, Campos OR, Roque CG, Dallacort R (2016) Efeito da profundidade de semeadura e presença de palha sobre o substrato na emergência de Crotalaria juncea. Ambiência 12(2):525-538.

ASAE. Agricultural tractor test code. In: ASAE standards 1989: standards engineering practices data. ASAE, 1989. p.44-48. (ASAE S209.5).
Betioli Junior E, Moreira WH, Tormena CA, Ferreira CJB, Silva AP, Giarola NFB (2012) Intervalo hídrico ótimo e grau de compactação de um Latossolo Vermelho após 30 anos sob plantio direto. Revista Brasileira de Ciência do Solo 36:971-982.

Beutler NA, Centurion JF (2004) Compactação do solo no desenvolvimento radicular e na produtividade da soja. Pesquisa Agropecuária Brasileira 39(6):581-588.

Beutler NA, Centurion JF, Roque CG, Ferraz MV (2005) Densidade relativa ótima de Latossolos Vermelhos para a produtividade de soja. Revista Brasileira de Ciência do Solo 29:843-849.

Cardoso RA, Bento AS, MOreski HM, Gasparotto F (2014) Influencia da adubação verde nas propriedades físicas e biológicas do solo e na produtividade da cultura da soja. Semina 35(2):51-60.

Cortez JW, Nagahama HJ, Olszevski N, Patrocinio Filho AP, Souza EB (2015) Umidade e temperatura de Argissolo Amarelo em sistemas de preparo e estádios de desenvolvimento do milho. Engenharia Agrícola 35(4):699-710.

Donagema GK, Campos DVB, Calderano SB, Teixeira WG, Viana JH (2011) Manual de métodos de análise de solos. Rio de Janeiro, Embrapa Solos, p. 230.

Edmond JB, Drapala WL (1958) The effects of temperature, sand and soil acetone on germination of okra seed. Proceedings of American Society Horticulture Science 71(2):428-34. 
Francetto TR, Alonço AS, Bellé MP, Franck CJ, Carpes DP (2015) Comportamento operacional de associações entre sulcadores e discos de corte para sistemas de semeadura direta. Engenharia Agrícola 35(3):542-554.

Frasier I, Quiroga A, Noellemeyer E (2016) Effect of different cover crops on $\mathrm{C}$ and $\mathrm{N}$ cycling in sorghum NT systems. Science of The Total Environment 562(4): 628-639.

Furlani CEA, Gamero CA, Levien R, Lopes A, Levien RP (2004) Desempenho operacional de uma semeadoraadubadora de precisão em função do preparo do solo e do manejo da cobertura de inverno. Engenharia Agrícola 24(2):388-395.

Gozubuyuk Z, Sahin U, Ozturk I, Celik A, Adiguzel MC (2014) Tillage effects on certain physical and hydraulic properties of loamy soil under a crop rotation in a semiarid region ith a cool climate. Catena 118:195-205.

Herrada MR, Leandro WM, Ferreira EPB (2017) Leguminosas isoladas e consorciadas com milheto em diferentes sistemas de manejo do solo no feijão orgânico. Terra Latinoamericana 35(4):293-299.

Lacerda JJJ, Resende AV, Furtini Neto AE, Hickmann C, Conceição OP (2015) Adubação, produtividade e rentabilidade da rotação entre soja e milho em solo com fertilidade construída. Pesquisa Agropecuária Brasileira 50(9):769-778.

Laflen JM, Amemiya M, Hintz EA (1981) Measuring crop residue cover. Journal of Soil and Water Conservation 36(6):341-343.

Lima LB, Petter FA, Leandro WM (2015) desempenho de plantas de cobertura sob níveis de compactação em Latossolo Vermelho de Cerrado. Revista Brasileira de Engenharia Agrícola e Ambiental 19(11):1064-1071.

Lima RP, Leon MJ, Silva AR (2013) Compactação do solo de diferentes classes texturais em áreas de produção de cana-de-açúcar. Ceres 60:16-20.

Marques JP, Benez SH (2000) Manejo da vegetação espontânea para a implantação da cultura do milho (Zea mays L.) em plantio direto e preparo convencional do solo. Energia na Agricultura 15 (1):13-26.

Matoso AO, Souza LCF, Andrade LHL, Pedroso FF, Costa NR (2015) Desempenho agronômico da cultura do milho sob diferentes plantas de cobertura no Cerrado. Tecnologia \& Ciência Agropecuária 9 (3):29-34.

Nagahama HJ, Cortez JW, Pimenta WA, Patrocínio Filho AP, Souza EB (2016) Sistemas de preparo e velocidade de deslocamento de conjuntos mecanizados em atributos do solo. Agrarian 9 (34):357-364.

Oliveira ML, Vieira LB, Mantovani EC, Souza CM, Dias GP (2000) Desempenho de uma semeadora-adubadora para plantio direto, em dois solos com diferentes tipos de cobertura vegetal. Pesquisa Agropecuária Brasileira 35 (7):1455-1463.

Ortiz S, Martin TN, Brum MS, Nunes NV, Stecca JDL, Ludwig RL (2015) Densidade de semeadura de duas espécies de ervilhaca sobre caracteres agronômicos e composição bromatológica. Ciência Rural 45(2):245-251.
Paz LB, Souza RL, Gomes SS, Santos LC, Silva RF

(2012) Produtividade de milho safrinha em consórcio com leguminosas em sistema orgânico. Cadernos de Agroecologia 7(2):1-5.

Pereira W, Leite JM, Hipólito GS, Santos CLR, Reis VM (2013) Acúmulo de biomassa em variedades de cana-deacucar inoculadas com diferentes estirpes de bactérias diazotrópicas. Ciência Agronômica 44(2):363-370.

Sá JCM, Tivet F, Lal R, Briedes C, Hartman DC, Santos JZ, Santos JB (2014) Long-term tillage systems impacts on soil $\mathrm{C}$ dynamics, soil resilience and agronomic productivity of a Brazilian Oxisol. Soil and Tillage Research 136:38-50.

Silva FA, Freitas FCL, Rocha PRR, Cunha JLXL, Drombroski JLD, Coelho MEH, Lima MFP (2015) Milho para ensilagem cultivado nos sistemas de plantio direto e convencional sob efeito de veranico. Ciências Agrárias 36(1):327-340.

Souza EB, Patrocínio Filho AP, Pimenta WA, Nagahama HJ, Cortez JW (2014) Resistência mecânica do solo à penetração em função da sua umidade e do tipo de penetrômetro. Engenharia na Agricultura 22(1):67-76.

Stolf R (1991) Teoria e teste experimental de formulas de transformação dos dados de penetrômetro de impacto em resistência do solo. Revista Brasileira de Ciência do Solo 15:229-235.

Stolf R, Fernandes J, Furlani Neto V (1983) Penetrômetro de impacto - modelo IAA/Planalsucar - Stolf. Stab 1(3):18-23.

Storck L, Modolo J, Brum B, Trogello E, Franchin MF, Adami PF (2015) Medida de regularidade do espaçamento de plantas de milho em diferentes sistemas de manejo. Revista Brasileira de Engenharia Agrícola e Ambiental 19(1):39-44.

Suzuki LEAS (2005) Compactação do solo e sua influência nas propriedades físicas do solo e crescimento e rendimento de culturas. Dissertação Mestrado Ciência do Solo, Universidade Federal de Santa Maria.

Suzuki LEAS, Reichert JM, Reinert DJ, Lima CLR (2007) Grau de compactação, propriedades físicas e rendimento de culturas em Latossolo e Argissolo. Pesquisa Agropecuária Brasileira 42(8):1159-1167.

Torres JLR, Pereira MG, Assis RL, Souza ZM (2015) Atributos físicos de um Latossolo Vermelho cultivado com plantas de cobertura, em semeadura direta. Revista Brasileira de Ciência do Solo 39:428-437.

Ziech ARD, Conceição PC, Luchese AV, Balin NM, Candiotto G, Garmus TG (2015) Proteção do solo por plantas de cobertura de ciclo hibernal na região Sul do Brasil. Pesquisa Agropecuária Brasileira 50(5):374-382. 